IBT Journal of Business Studies

Volume 14(2), 41-52, 2018

\title{
Consumer Acceptance of Online Banking: Application of Technology Acceptance Model
}

\author{
Sobia Zaman ${ }^{1}$ \\ Hamza Bhatti ${ }^{2}$ \\ Mian Asif Khurshid ${ }^{3}$
}

\begin{abstract}
This research reports the findings of a study concerning the acceptance of online banking in Pakistan. It investigates customer's adoption within the context of Pakistan online banking services whereby the research frame work is based on the extension of Technology Acceptance Model. The research model included factors that would influence the acceptance of online banking. The frame work dimensions includes online banking usage, quality of internet connection, perceived enjoyment, perceived usefulness, perceived ease of use and security \& privacy. A survey was conducted to gather the data for study. Reliability, correlation and factor analysis were used to analyse the data. Results showed that quality of internet connection, amount of information on online banking and security and privacy has positive influence on online banking usage. Theoretical contributions and practical implications of the findings are discussed in the paper and suggestions for future research are proposed.
\end{abstract}

Keywords: Online Banking, Attitude, TAM, Perceived Enjoyment, Security \& Privacy

1- Department of Management Sciences Bahria University Islamabad Pakistan, zamansobia@hotmail.com

2- Department of Management Sciences Bahria University Islamabad Pakistan, hamzabhatti08@gmail.com

3- Department of Management Sciences Bahria University Islamabad Pakistan, asif.k.mian@gmail.coM 


\section{INTRODUCTION}

As the field of information and communication technology advances, the growing use of internet can be witnessed in almost every business. It can be seen particularly in business transactions having significant impact over banking industry. This is becoming a global trend, however comparative to developed countries, internet banking has far low penetration in under developed countries (Alalwan, Dwivedi, Rana, Lal, \& Williams, 2015).Hence, academic researchers are examining the factors having impact over user's behaviorintention towards adopting innovation in information technology (Khalil, Pearson \& Ahmad, 2010; Davis et al., 1989; Mathieson, 1991; Davis and Venkatesh, 1996). Technology Acceptance Model (TAM) proposed in 1989 by Davis is a widely accepted model due to its precise emphasis on the usage of Information System (IS). Its foundation can be found from empirical evidence of various studies in social psychology. According to TAM, technology adoption behavior can be determined by the intention to utilize which is further determined by the perceived usefulness and perceived ease of use.

Banking industry has always relied on information technology for gathering, processing and delivering information to all users. In 1969 after the invention of internet computers became an important channel of communication (Nehmzow, 1997). Internet is becoming a key element in supply channel and is allowing banking to provide alternative channel to consumers for product and services and therefore banks are reevaluating their IT systems to remain contemporary and fulfil customer's need. Due to lack of time and busy routine, customer require extra convenience and flexibility along with easy to use financial management tools and product/ services that conventional banking system is not able to offer. Online banking and financial institutions allows provisioning of these services by using extensive public network infrastructure (Szopiński, 2016).However, the structure and timebased separation of e-commerce among customers and retailers along with volatility of the internet infrastructure generates uncertainty about online services. Similarly, early adoption of the services such as online banking requires acceptance by both information technology and the online service providers. Technology Acceptance Model (TAM) was presented by Fred Davis (1989) centered on belief-attitude-intention-behavior relationship. This model is basically an extension of Theory of Reasoned Action (TRA) and intended for the willingness of information system usage. According to Davis (1989) there are two factors which play an important role towards the acceptance or rejection of the technology. First is 'Perceived Usefulness (PU)' i.e. the extent to which an individual believe by using or rejecting a system help to perform tasks even better. Second is 'Perceived Ease of Use (PEOU)' i.e. the extent to which an individual believes that using a particular system would be free of effort. Davis et al. (1992) defined, enjoyment is as internal reward that an individual receive through the use of the technology. Unlike external motivation like PU which relies on attainment of related goals or reward, internal motivation states the internal pleasure that an individual receive by performing an activity. Davis et al. (1992) added perceived enjoyment to the originally devised TAM and identified it as a significant dimension for technology adoption intention.

Jahangir \& Begum (2008) found out that four determinants that can effect online baking usage includes security and privacy, perceived ease of use, perceived usefulness, and customer attitude. Pikkarainen et al. (2004) used the conservative TAM and suggested that PU, PEOU, along with privacy and security are the determinant which may effect the acceptance of online banking. Security can be defined as 'the state of being free from danger and 'privacy' can be defined as the state of being free from unwanted or undue intrusion or disturbance. Delayed transactions and slow responses is responsible for loosing confident while using online banking services (Jun and Cai, 2001).For speedy download of the information the internet connection is essential (Jayawardhena and Foley, 2000). Quality of internet connection is becoming an important determinant that can influence the acceptance or rejection of online banking. The same argument is supported by Poon (2008) mentioning that quality of internet connection has influence on usage of online banking. 
In Pakistan, there exist an extensive network of conventional branch based retail banking system. However, with the rapid increase in the technology, specifically with growth of internet, designing and deliveringof financial services has changed. Commercial banks in Pakistan are trying to change the dynamics of banking from conventional based services to online based services to improve operations and to reduce cost. Efforts are being made by banks to make the customers use online banking services, but still majority of customers could not be converted. The use of online banking is increasing but at slow pace, hence there exist a need to have a sound understanding of internet banking by the users and the practitioners need to know the potential determinants that may effect internet banking. This study has tried to examine the determinants influencing online banking adoption by Pakistani customers.

\section{LITERATURE REVIEW}

Organizations spend significant amount from their budget on information system to get maximum benefits such as cost reduction and quality improvement of their products and services (Lederer et al., 1998). However if users do not respond positively towards IT theninternet banking cannot reach to the maximum utility of the organization (Davis, 1993). Venkatesh (1999) suggested that to have maximum utility in the organization through information technology it needs to be accepted and fully used by the end users. Swanson (1988) states that individual behavior towards technology acceptance or rejection has been the most challenging issue and helps the designers and developers to develop products that motivate people to utilize it at maximum level.

Lack of research in IT leads researcher to link their finding with models developed in other studies for example, intention models have been derived from social psychology. A literature review reveals that many models have been used to study individual's adoption and usage behaviour of new technology such as the Innovation Diffusion Theory IDT (Rogers, 1983), the Theory of Reasoned Action TRA (Fishbein \& Ajzen, 1975; Ajzen \&Fishbein, 1980), the Theory of Planned Behavior TPB (Ajzen, 1991), the Technology Acceptance Model TAM (Davis, 1989) and the Task Technology Fit model TTFM (Goodhue \& Thompson, 1995).

\section{Online Banking}

According to Online Banking Comptroller's Handbook (1999), online banking is system which empower bank customers to have access to the accounts of customers and product general information through computers or other online platforms. Online banking according to researchers is to enable customers to access banks accounts and carry transactions through online platforms. Online banking offers products and services same as conventional banks offerswhen a customer visits the branch.In last few years, acceptance of online banking has increased, for instance Europe is the pioneer in the usage and innovation of online banking (Schneider, 2001). Towards the end of year 2000, around 20 percent of banks in the US offered online banking services (Orr, 2000; Sheshunoff 2001) and before year end 2002 around 120 biggest banks in US made access of online banking to its users (Pyun et al., 2002). It has been observed that users' state of mind to accept or reject technology innovation has an effect on successful selection of information system (Davis, 1989; Venkatesh and Davis, 1996; Succi and Walter, 1999). As the users are willing to accept new technology they make some alterations to the practices, utilize time and use technology innovation (Pikkarainen et al, 2004).

\section{Technology Acceptance Model}

Technology Acceptance Model (TAM) was proposed by Fred Davis (1989) based on belief-attitudeintention behavior relationship. This model is fundamentally an augmentation of Theory of Reasoned Behavior (TRA) intends for the acknowledgement of information system by users. TAM is essentially a theory on information system which tries to clarify the user acknowledgment of innovation in 
information technology. Davis et al.(1989) claims 'the objective of using Technology Acceptance Model is to give overall clarification that the factors impact while accepting the technology. TAM has been widely applied by information system researchers as it supports parsimony and empirical of wealth (Agarwal, Yadav \& Prasad, 1999; Adams et al., 1992; Hardgrave, \& Johnson, 2003). Application of TAM has also been seen in various technologies, like software related to spread sheet, email, voice mail, the World Wide Web, graphics software and in technology regarding tele-medicine (Adams et al., 1992; Mathieson, 1991,taylor, \& Straub, 2000; Hu \&2001). Davis and Venkatesh (2000) suggested that TAM's applicability in technologies can be on a broadrange. In the context of web, Calantone and Gentry (2002) described usage of shop bot through web by performing a comparison study based on three models: TRA, TPB and TAM. The results showed that all models works in the same context however TAM had an advantage on TRA and TPB for explaining difference in behaviors intentions from model fit context.As TAM previously has been experimented in various environmental settings and on different applications, the results appear were inconsistent and contradicting (Legris et al., 2003). Like there were studies conducted showing that both PU and PEOU influences intention (Moon, Simon \& Kim, 2001; Tang \& Chiang, 2009 Simon \& Paper, 2007) or it is only influenced by PU (Gefen, Bosnjak \& Straub, 2000; Cheng et al., 2006; Hu et al., 2003;). Some studies discovered that perceived ease of use considerably impact PU (Lin, 2007; Shih, 2004), whereas other suggests this relation is not significant (Wu et al.,2007; Hwang, 2005). There are explanations for such differences such as; technology that has been studied is different,sample size that has been engaged is different with respect to experience and inexperience and countries and environmental differences.

\section{Attitude}

TAM proposed behavioral expectations are determined by the state of mind of the person towards acceptance of a system and PU (Davis et al., 1989). In this manner explanation propose that fundamental theoretical concept of TAM included the attitude construct. However it was later discovered that the TAM's power even without having attitude construct is equally great and parsimonious (Davis et al., 1989). Removal of 'attitude' from TAM was justified by three reasons; firstly a direct link was there between perceived usefulness and intentions both. Secondly a weak link exist between PEOU and attitude. Third, the impact of beliefs on intentions was partially mediated by attitude. Davis et al. (1989) recommends the application of TAM applied in a setting where components like ease of usefulness or usefulness are independently taken into consideration and insignificant element of intention is the attitude. Jackson et al. (1997) second this by guaranteeing 'attitude, as another conduct related factors and not just a criteria of achievement. Therefore due to these reasons analysts applied innovation acceptance without considering attitude dimension (Vankatesh, 2000; Hong et al., 2002; Hwang \& Lord, 2005; Chang \& Chau, 2008; Calisir \& Gumussoy, 2009).

\section{Perceived Usefulness}

TAM emphasizes on acceptance or rejection of innovation by the users (Davis, 1989). It outlined IT related item in an organizational setting. The fundamental components of this model are perceived usefulness and perceived ease of use (Davis, 1989). Perceived usefulness can be characterized as to what extent a man finds that utilizing information technology will increase his or her performance in the job. Perceived usefulness and perceived ease of use are proved to be the most significant factors influencing adoption and usage of online banking services (Bankole et al., 2011; Shaikh \& Karjaluoto, 2015). PU relies on perceived significance of a specific technology such as does the information sounds good to users, the significance of the goal that an individual sawi.e. how learning is identified with the assignment, the apparent validity of the operations i.e. is it able to connect that learning to some place, and the apparent ingenuity i.e. how new the information is. Researcher additionally utilize TAM in settings of private individual, since this theory is applicable outside the organizational 
setting too. Davis (1989) pin point the significance of PU due to functionality as to how simple or hard to perform desired functions. It implies that to get a good score in PEOU could not able to pay for an application/system that considered useless by the users. TAM can be extremely valuable for the utilization of online banking(Lee\& Lanting, 2011).The role of PU have been supported by many researchers as it influence intention and behavior of user (Todd \& Taylo, 1995b; Davis \&, Venkatesh 1996). Chau (2000) bifurcated PU into perceived long term usefulness and perceived near term usefulness along with speculated behavior intention as to utilize an innovation. Chau (2000) studied the utilization software packages by 285 subjects and it was seen that perceived near term usefulness had significant relation with intention towards usage of the technology then by perceived long term usefulness.

\section{Perceived Ease of Use}

Perceived ease of use is characterized as 'how much a man trusts that utilizing aspecific system would be free of efforts' (Davis,1989). The expression ease from thedefinition allude to the 'flexibility from the trouble. Effort is a constrainedasset that a man may allocate to the exercises that he or she is answerable to and the application isseen to be less demanding as contrast with other. Variable that are external like qualities of users, tasks, politicaleffect, organizational factors can affect innovation acceptance conduct in indirect way byinfluencing PU and PEOU (Szajna, 1996).Interestingly the part of PEOU in TAM in earlier reviews has purportedly been distinctive.Straub and Gefen (2000) asserted that part of PEOU is complex than earlier reviews revealedit. They communicated that apparent usability is driven by inspiration that depends on theappraisal of convenience and simplicity of learning of the interfaces and procedure whileutilizing it, which can indicate as inherent part of data innovation. As most reviews assembledoutward part of data innovation, perceived ease of use does not influence adoption of the technology.

\section{Perceived Enjoyment}

TAM first distinguished PEOU and PU as basic component of usage intention. Later newfactors having impact on utilization behavior havebeen added to the model. There can be three ways to deal with the presentation of new elements, for instance, subjective standard, perceived behavioral control and perceived resources. It is concluded that perceived behavioral control (Chau and $\mathrm{Hu}, 2002$ ) and perceived enjoyment have an impact on proposed usage of behavior. Perceived Enjoyment (PE) is characterized as natural reward inferred using the innovation. Unlike external motivation like PU which depends on fulfilment of particular goals or reward, internal motivation states to the delight of doing any movement independent from anyone else. Davis et al. (1992) added PE as factor to originally proposed TAM and discovered its high impact on goal selection in embracing an innovation. The central presumption of the review is that enjoyment would specifically characterize proceeded with utilization of the application. This is established from the work of Davis et al. (1992) and other researchers. Additionally, the primary motivation behind utilizing any technology is to bring convenience tothe users. Notwithstanding the PE, flow and perceived playfulness are the two moredimension influencing the behavior. Flow is habitually seen as identical to the playfulness which depends on four key measurements such as; intrinsic interest, curiosity, attention focus and control (Webster,Agarwal, Karahanna 2000, Moon, Kim 2001). Sherry (2001) states that PU has several part of as in flow. Despite the fact that fervor is highlighted as analternate feeling of enjoyment (Sherry 2004, Boyle et al.2012). This review concentrates PU as its relevance in internet banking is key determinant and its estimation scale is also settled and predictable than other two. Venkatesh and Davis (2000) and Chau and $\mathrm{Hu}$ (2002) explored the effect of subjective standard on behavioral goal to utilize. Empirical outcomes from past reviews demonstrated blend discoveries for SN construct, as subjective standard was an mperative determinant of behavioral intention in a research driven by Venkatesh and Davis (2000). 
Despite the fact that the aftereffects of Chau and $\mathrm{Hu}$ (2002) discovered subjective standard was inconsequential factor to utilize. Literature revealed that perceived resources was an essential factor of behavioral aim. Moreover PU (Shaikh \& Karjaluoto, 2015) and perceived behavioural control (Chau and $\mathrm{Hu}, 2002$ ) are also found to have critical impact on behavioral aim. In an attempt to examine online banking acceptance, Pikkarainen et al. (2004) identified four factors of TAM display derived from past review and from meetings with managing banking professionals. Aside from fundamental factors of Technology Acceptance Model (PU and PEOU) different factors added were security and privacy, information on online banking, perceived enjoyment and the quality of the Internet connection. The customers who had an ordeal of online banking was tried with 315 in the extended model. The aftereffect of the review revealed that perceived usefulness and information on online banking were the essential determinants of technology acceptance model.

\section{Security and Privacy}

Trust and security are found to be important factors that influence attitude towards online banking (Khalil and Pearson, 2015; Tarhini, Mgbemena, Trab, \& Masa'deh, 2015).Online banking have been studied by many researchers. Jahangir \& Begum (2008) highlighted four factors which influence the online baking usage. These factors includes PU,PEOU, security and privacy and customer attitude. Among these four factors, users are most influenced by privacy and security in terms of online banking. Pikkarainen et al. (2004) used the conventional TAM and recommended that PU, PEOU along with privacy and security were the vital components identified for adoption of online banking. Security can be defined as 'the state of being free from danger and threat' the context of security used here is the amount of information which is secure and not shared with anyone without any prior permission and privacy can be defined as 'the state of being free from unwanted or undue intrusion or disturbance and it is the capacity of an individual or group to isolate themselves, or information about themselves' and thereby express themselves selectively. In many banking studies security and privacy has the significance towards the approval of internet banking (Johanson, 2016; Howcroft et al., 2002; Black et al., 2002; Polatoglu and Ekin, 2001; Giglio, 2002; Howcroft et al., 2002; Tan and Teo, 2000). The main obstacle in accepting online banking is the security and privacy issues (Sathye, 1999). Roboff and Charles (1998) explored that user have limited knowledgeon risks related to security in online banking yet they know the risk. Moreover it was discovered that privacy issues related to internet depends on their bank and bank protects them. Lastly an argument is made that though consumers have strong confidence towards banking but towards technology their confidence is weak (Howcroft et al., 2002). A number of studies (Westin and Maurici, 1998; Cranor et al., 1999) show that privacy problems have proven to be a key hurdle towards the acceptance of internet banking.

\section{Quality of Internet Connection}

For speedy download of information a good internet connection is essential (Jayawardhenaand Foley, 2000). Delayed transactions and slow responses are reasons for loosing customer's confidence while using online banking services (Cai and Jun, 2001). The quality of internet connections is noticeably one of the critical element that contribute to acceptance or rejection of online banking and if there is no appropriate internet connection then online banking would not be attractive. (Sathye, 1999; Pikkaranainen, 2004). The same argument is supported by Poon (2008) internet connection's quality does impact the experience of using online banking. While an attempt is made to boost the application of internet, Malaysian government has especially allocated a grant to the operators which was found helpful although it was limited (Mansor and Abidin, 2010). Some thoughtful consideration is needed to build confidence in onsumers (Chen and Yen, 2004) along with individual as to make routine transaction using online banking platforms 


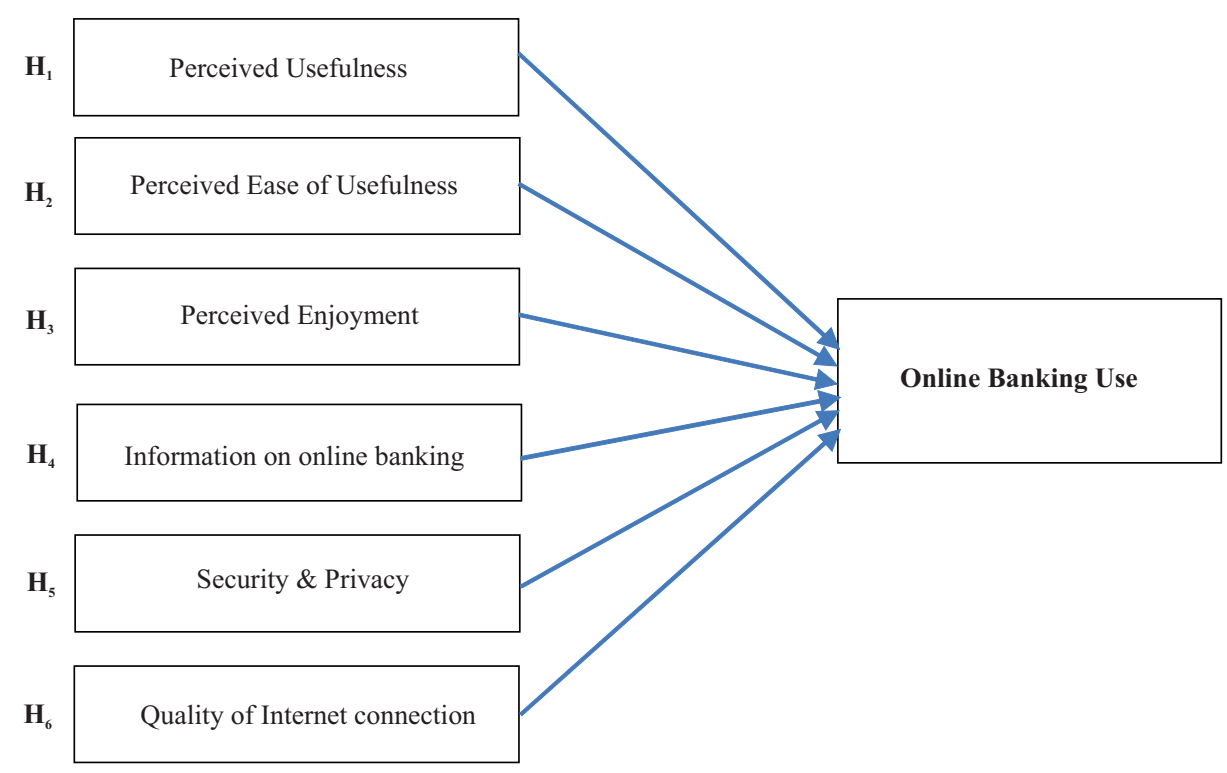

Figure .1: Research Model

\section{METHODOLOGY}

For this study data from different banks, financial intuitions and universities within Rawalpindi and Islamabad was collected. A survey was conducted for collecting the data, whereby a total of 370 questionnaires were distributed in hard and soft form out of which 315 respondents return it. After collection of data, it was filtered for missing values and literal error. Regression analysis e was used to find association among and influence of factors of using online banking. The purpose behind this survey was to comprehend the factors influencing online banking acceptance. A framework was designed to investigate the accumulated data. The statistical techniques used in this study were reliability statistic of individual variable and overall, regression analysis, correlation and factor analysis. Furthermore t-statistic, R-squared for the model significance, ANOVA and rotated component matrix were applied. The usage of online banking is used as dependent variable of the study. There are six independent variables chosen for the research which included quality of internet connection, amount of information on online banking, perceived enjoyment, perceived usefulness, perceived ease of use and security and privacy. Questionnaires were distributed to public and private banks, financial institutions and to university students. Convenience sampling technique was adopted for sample selection such as customers, employees and student of different universities. The researcher, for the sake of data collection went to the banks mostly on weekdays. The research instrument was adapted from Davis (1989) having a total of 41 questions in which five questions were related to demographics while remaining 36 questions were related to dependent and independent variables of the study. Five-point Likert scale was utilized ranging from 'strongly disagree' to 'strongly agree'.

\section{DATAANALYSIS}

Internal consistencies of the variables used in the study are considered as acceptable since overall variables exceeds to .70 , suggesting tolerable reliability. See Table.1. The overall reliability of the scale is .946. 


\begin{tabular}{|l|l|}
\hline \multicolumn{2}{|c|}{ Table.1: Composite Reliability of Constructs } \\
\hline Name of construct & Composite Reliability \\
\hline & \\
\hline Usage of online banking & 0.723 \\
\hline Quality of internet connection & 0.916 \\
\hline Amount of information on online banking & 0.77 \\
\hline Perceived enjoyment & 0.904 \\
\hline Perceived usefulness & 0.931 \\
\hline Perceived ease of use & 0.911 \\
\hline Security \& Privacy & 0.779 \\
\hline Overall dependent \& independent constructs & 0.946 \\
\hline
\end{tabular}

The factor analysis was studied by using principal component with varimax rotation on extraction method (refer details Nummenmaa et al., 1996, p. 244; Aczel, 1999, pp. 814-18; Hair et al., 1998, pp. 87-120). The Bartlett's test of sphericity established that either the variables are correlated within factors. Kaiser-Meyer-Olkin (KMO) Test is a measure if relevant the data is for Factor Analysis. KMO values should be in the range between 0.8 and 1 indicate the sampling is sufficient that the data is suitable to run factor analysis.

Table.2: Bartlett's \& KMO Test

\begin{tabular}{|cc|c|c|c|}
\hline KMO Measure of Sampling & Adequacy & Chi-Square & Bartlett's Test Sphericity & \\
\hline \multirow{2}{*}{0.951} & \multirow{2}{*}{9165} & Df & Sig \\
\cline { 3 - 4 } & & 741 & 0 \\
\hline
\end{tabular}

The Kaiser-Meyer-Olkin (KMO) measure adequacy of the sampling demonstrated a useful level of common variance and its value is 0.951 (Table-2) which indicates that data is adequately suitable enough to run factor analysis. The regression analysis was conducted to disclose the different factors that affect the acceptance of online banking. To access this, we need to check the fitness of the model run regression analysis and the calculated value of significance in .000 which revealed that model is fit for use, the Table-3 of ANOVA is presented below.

\begin{tabular}{cccccc}
\hline Model & Sum of Squares & Df & Mean Square & F & Sig \\
\hline Regression & 12.405 & 6 & 2.067 & 8.96 & 0.0006 \\
Residual & 71.067 & 308 & 0.0231 & & \\
Total & 83.471 & 314 & & & \\
\hline
\end{tabular}

a. Dependent Variable: Usage of online banking

b. Predictors: (Constant) Privacy and Security, Measure of Information, Internet connection quality,

PE,PU,PEOU

Among the variables under study only the coefficients quality of internet connection $(t=1.907$, $\mathrm{p}=0.4$ ), amount of information $(\mathrm{t}=2.183, \mathrm{p}=.030)$ and security and privacy $(\mathrm{t}=3.581, \mathrm{p}=.000)$ are statistically significant, while rest of the variable are insignificant and value of R2 is 0.149 .

\begin{tabular}{|l|c|c|c|c|c|}
\hline \multicolumn{7}{|c|}{ Table .4 } \\
\hline Model & $\begin{array}{c}\text { unstandardized } \\
\text { coefficient }\end{array}$ & & $\begin{array}{c}\text { standardized } \\
\text { coefficient }\end{array}$ & t & sig \\
\hline & B & std. error & Beta & & \\
\hline \hline Constant & 1.5 & 0.1 & 0.13 & 14.22 & 0 \\
\hline $\begin{array}{l}\text { Quality of Internet } \\
\text { connection }\end{array}$ & 0.76 & 0.4 & 0.14 & 1.9 & 0.37 \\
\hline Amount of Information & 0.096 & 0.44 & -0.65 & 2.18 & 0.3 \\
\hline Perceived enjoyment & -0.46 & 0.68 & -0.2 & -0.68 & 0.49 \\
\hline Perceived Usefulness & -0.13 & 0.74 & -0.47 & -0.17 & 0.86 \\
\hline Perceived Ease of Use & -0.31 & 0.85 & 0.29 & -0.36 & 0.71 \\
\hline Security \& Privacy & 0.2 & 0.56 & & 3.58 & 0 \\
\hline
\end{tabular}


From the regression analysis it was found out that the model is fit as significance value of $\mathrm{F}$ is 0.000 and value of R2is 0.149 . From the coefficient table it was suggested that only $\mathrm{H}_{1}, \mathrm{H}_{2}$ and $\mathrm{H}_{6}$ are statistically significant while rest of them are insignificant as shown in Table- 4 .

\begin{tabular}{|c|c|c|c|}
\hline \multicolumn{5}{|c|}{ Table .4(a) :Hypothesis } \\
\hline Hypothesis & T-Statistics & Significance & Remarks \\
\hline H1 & 1.9 & 0.37 & Supported \\
\hline H2 & 2.183 & 0.3 & Supported \\
\hline H3 & -0.68 & 0.497 & Not supported \\
\hline H4 & -0.177 & 0.86 & Not supported \\
\hline H5 & -0.367 & 0.714 & Not supported \\
\hline H6 & 3.581 & 0 & Supported \\
\hline
\end{tabular}

Thus, from the hypothesis it is confirmed that the PE, PU and PEOU are not supported by data. Therefore, quality of internet connection, amount of information on online banking and security and privacy has been statistically supported.

\section{CONCLUSION \& RECOMMENDATION}

The primary goal of this research was to understand the determinants having influence on acceptance of online banking usage from the technology acceptance perspective (TAM) with added variables taken from literature of online banking. The model was suggested variables of online banking with modelled variables which originate from the TAM and four other variables including perceived enjoyment (PE), information on online banking, security and privacy, and the quality of the internet connection. The analysis already discussed different tests run with 315 filled questionnaires that includes reliability analysis, regression analysis and factor analysis. The results suggest that the Cronbach's alpha of the individual variables and overall the value is greater than 0.70 suggesting acceptable reliability. From hypothesis it is confirmed that perceived enjoyment, perceived usefulness and perceived ease of use are not supported by the data whereas quality of internet connection, amount of information on online banking and security and privacy have been statistically supported.

It is recommended to banks' regulatory authority to design strategies to encourage customers use online banking system, as there isn't any involvement of cash, travelling etc. As in the study all variables related to perceived enjoyment, usefulness and ease of use are insignificant, it may be due to lack of awareness hence effective advertisement campaigns can result in positive customer perception about effectiveness of using online banking. Banks can share information related to uses of online banking in order to facilitate customers and make efforts to remove barrier highlighted in the study that hinder use of online banking. Providing safe, secure and reliable internet banking services can also enable customers to use online banking. Banks should provide easy to understand guidelines through their recognized platforms in order to influence customer towards online banking. The main concern associated with online banking is the risk and it can be minimize by providing strict check and balance and error free system to let their customers trust online banking services. Such steps will help to build a positive image of online banking in the mind of customers. In future studies can be done by expanding sample size that provide more insight and in-depth results. Control variables like level of education, professional experience and gender can also be used to see its influence on usage of online banking.

\section{REFERENCES}

Adams, D., Nelson, R. \& Todd, P. (1992). 'Perceived usefulness, ease of use, and usage of information technology: a replication.' MIS Quarterly, Vol.16, pp.227-247.

Agarwal, R. \& Prasad, J. (1999). 'Are individual differences germane to the acceptance of new information technologies?' Decision sciences, Vol.30, pp.361-391.

Ajzen, I. \& Fishbein, M. (1980). 'Understanding attitudes and predicting social behavior,Englewood 
Cliffs,' N.J., Prentice-Hall.

Alalwan, A. A., Dwivedi, Y. K., Rana, N. P., Lal, B., \& Williams, M. D. (2015). Consumer adoption of Internet banking in Jordan: Examining the role of hedonic motivation, habit, self-efficacy and trust. Journal of Financial Services Marketing, 20(2), 145-157.

Bankole, F. O., Bankole, O. O., Brown, I., 2011. Mobile banking adoption in Nigeria. The Electronic Journal on Information Systems in Developing Countries 47(2), $1-23$.

Black, P. J.; Harrison, C.; Lee, C.; Marshall, B. \& Wiliam, D (2002). 'Working inside the black box: Assessment for learning in the classroom'. London, UK: nferNelson

Chang, H. (2008). 'Intelligent agent's technology characteristics applied to online auctions'task: A combined model of TTF and TAM.' Technovation, Vol. 28, pp.564-577.

Chau, Y.K. Hu, J.H (2000), Information technology acceptance by individual professionals: a model comparison approach, Decision Science, Vol.34, No.4 pp.699-719.

Chen, K. and Yen, D. (2004). Improving the Quality of Online Presence Through Interactivity, Information and Management, 42(1), pp. 217-226.

Davis, F.D. (1989). Perceived Usefulness, Perceived Ease of Use, and User Acceptance of Information Technology. MIS Quarterly, Vol. 13, No 3, pp. 318-339.

Fishbein, M. \& Ajzen, I. (1975). 'Belief, attitude, intention and behavior: An introduction to theory and research. Reading,' MA:Addison-Wesley.

Gentry, L., and Calantone, R. (2002). "A comparison of the three models to explain Shop- bot use on the web". Psychology \& Marketing, Vol.19 No.11, pp. 945-956.

Goodhue, D. \& Thompson, R. (1995). 'Task-technology fit and individual performance.' MIS Quarterly. 19,213-236.

Hardgrave, B. \& Johnson, R. (2003). 'Toward an information systems development acceptance model: the case of object-oriented systems development.' IEEE Transactions on Engineering Management, Vol.50, pp.322-336.

Hong, W., Thong, J., Wong, W. \& Tam, K. (2002). 'Determinants of user acceptance of digital libraries: an empirical examination of individual differences and system characteristics.' Journal of Management Information Systems, Vol.18, pp.97-124.

Howcroft, B., Hamilton, R., and Hewer, P. (2002). 'Consumer attitude and the usage and adoption of home-based banking in the United Kingdom.' International Journal of Bank Marketing, Vol. 20 No. 3, pp. 111-21.

Hu, P.J.H., Ma, P.C. and Chau, P.Y.K. (1999b).'Evaluation of user interface designs for information retrieval systems: a computer-based experiment.' Decision Support Systems, Vol.27, pp.125-143.

Hwang, Y. (2005). 'Investigating enterprise systems adoption: uncertainty avoidance, intrinsic motivation, and the technology acceptance model.' European Journal of information Systems, 14, 150-161.

Jackson, C., Chow, S. \& Leitch, R. (1997). 'Toward an understanding of the behavioral intention to use an information system.' Decision sciences, Vol.28, pp.357-389.

Jahangir, N. and N. Begum (2008), "The role of perceived usefulness, perceived ease of use, security and privacy, and customer attitude to engender customer adaptation in the context of electronic banking," African Journal of Business Management, 2(1), 32-40.

Jayawardhena, C. and Foley, P., (2000). Changes in the banking sector: the case of internet banking in the UK. Internet Research: Electronic Networking Applications and Policy, 10 (1), pp.1930.

Johansson, A. (2016). Security and internet banking: How satisfied are users with internet banking security?

Jun, M. and Cai, S., (2001). The key determinants of internet banking service quality: a content analysis. International Journal of Banking Marketing, 19(7), pp. 276-291.

Kim, J.K., T.Y. Moon and I.B. Yoon (2001) Systematics of Vespine Wasps from Korea, I. Genus Vespa Linnaeus (Vespidae: Hymenoptera). Korean J. Entomol. 24(2):107- 115.

Lederer, A., Maupin, D. Sena, M. \& Zhuang, Y. (1998). The role of ease of use, usefulness and attitude 
in the predicting of World Wide Web usage. In proceeding of the 1998

Association for Computing Machinery Special Interest Group on Computer Personal Research Conference, 195-204.

Lee, K. W., Tsai, M. T., \& Lanting, M. C. L. (2011). From marketplace to marketspace: Investigating the consumer switch to online banking. Electronic Commerce Research and Applications, $10(1), 115-125$.

Legris, P., Ingham, J., Collerette, P., (2003), "Why do people use information technology? A critical review of the technology acceptance model", Information \& Management, Vol. 40, No.3, pp.191-204.

Mansor, N. and Abidin, F (2010). 'The application of E- Commerce Among Malaysian Small Medium Enterprises', European Journal of Scientific Research, Vol 41, Issue 4, pp 591 - 605.

Mathieson, K. (1991). 'Predicting user intentions: comparing the technology acceptance model with the theory of planned behavior'. Information System Research, Vol.2, No.3, pp.173-191.

Md Nor, K., Pearson, J. M., \& Ahmad, A. (2010). Adoption of internet banking theory of the diffusion of innovation. International Journal of Management Studies (IJMS), 17(1), 69-85.

Nehmzow, C. (1997). 'The internet will shake Banking Mediveal Fondations,' Journal of Internet Banking and Commerce, Vol. 2, No.2.

Nor, K. M., \& Pearson, J. M. (2015). The influence of trust on internet banking acceptance. The Journal of Internet Banking and Commerce, 2007.

Orr, B. (2001), "E-banking: what next?”, ABA Banking Journal, pp. 40-6.

Pikkarainen, T., Pikkarainen, K., Karjaluoto, H., Pahnila,S., (2004), 'Consumer Acceptance of online banking: an extension of the technology acceptance model'. Internet Research, Volume 14 No. 13, pp,224-235.

Polatoglu, V.N. and Ekin, S. (2001), "An empirical investigation of the Turkish consumers' acceptance of Internet banking services", International Journal of Bank Marketing, Vol. 19 No. 4, pp. 156-65.

Pyun, C.S, Les, S., \& Kiseok, N. (2002). 'Internet banking in the U.S., Japan and Europe.' Multinational Business Review, 10(2), 73.

Roboff, G. and Charles, C. (1998), "Privacy of financial information in cyberspace: banks addressing what consumers want", Journal of Retail Banking Services, Vol. XX No. 3, pp. 51-6.

Sathye, M. (1999). 'Adoption of internet banking by Austrailian consumer: an empirical investigation'. International of Bank Marketing, Vol.17, No. 7, pp.324-334.

Schneider, I. (2001), "Is time running out for Internet-only banks?", Bank Systems \& Technology, September, p. 8.

Shaikh, A., \& Karjaluoto, H. (2015). Mobile banking adoption: A literature review. Telematics and Informatics, 32 (1). doi:10.1016/j.tele.2014.05.003.

Sherry, J.L., (2004). Flow and Media Enjoyment. Communication Theory, vol. 14, no. 4, pp. 328-347.

Sheshunoff, A. (2000), "Internet banking - an update from the frontlines", ABA Banking Journal, January, pp. 51-3.

Straub, D., Keil, M. \& Brenner, W. (1997). 'Testing the technology acceptance model across cultures: A three country study.' Information \& Management, Vol. 33, pp.1-11.

Succi, M.J. and Walter, Z.D. (1999), "Theory of user acceptance of information technologies: an examination of health care professionals", Proceedings of the 32nd Hawaii Conference on System Sciences (HICSS), pp. 1-7.

Swanson, E. (1988). 'Information System Implementation: Bridging the gap between design and utilization.' Irwin. Homewood. IL.

Szajna, B. (1996). 'Empirical evaluation of the revised technology acceptance model'. Management Sciences Vol. 42 No.1 pp.85-92.

Szopiński, T. S. (2016). Factors affecting the adoption of online banking in Poland. Journal of Business Research, 69(11), 4763-4768.

Tarhini, A., Mgbemena, C., Trab, M. S. A., \& Masa'deh, R. (2015). User adoption of online banking in Nigeria: A qualitative study. The Journal of Internet Banking and Commerce, 20(3). 
IBT Journal of Business Studies

Taylor, S., Todd, P.A., (1995). 'Understanding information technology usage: a test of competing models. Information System Research, Vol.6, No. 2, pp.144-176.

Venkatesh, V. (2000). 'Determinants of perceived ease of use: Integrating control, intrinsic motivation, and emotion into the technology acceptance model.' Information systems research, Vol.11, pp.342-365.

Venkatesh, V. and Davis, F.D. (1996). 'A model of the Perceived Ease of Use: Development and Test', Decision Sciences, Vol.27, No. 3 pp.451-481.

Westin, A.F. and Maurici, D. (1998), "E-commerce \& privacy: what the net users want", Privacy \& American Business, and PricewaterhouseCoopers LLP, New York, NY. 